\title{
Pengaruh Model Pembelajaran Jigsaw dan Teams Games Tournament Terhadap Karakter Kepedulian Sosial dan Kejujuran dalam Pendidikan Jasmani Olahraga Kesehatan
}

Achmad Wardana $^{\mathrm{a} *}$, Anung Priambodo ${ }^{\mathrm{b}}$, Made Pramono ${ }^{\mathrm{c}}$

a,b,c Universitas Negeri Surabaya, Indonesia

Correspondence: achmadwardana1992@gmail.com

Received: 16 Jan 2020 Accepted: 24 Apr 2020 Published: 29 Apr 2020

\begin{abstract}
This study generally aims to reveal differences in the level of characters social caring and honesty based on gender resulting from learning physical sports and health educarion (PJOK) through the treatment of Jigsaw learning models and teams games tournament. The research method used was experimental research with a $2 \times 2$ factorial design. The instrument used was a questionnaire character of social caring and honesty that had been validated and filled out by students who took part in the research program. The research data collected in the form of the result of the pretest and posttest data were processed through the SPSS program version 20 with the hypotesis test of factorial twoway-anova analysis. The results of the study can be concluded that (1) there is no differnce in the level of social caring characters from the treatment of Jigsaw learning models and teams games tournament in PJOK learning, (2) there is no difference in the level of social caring character based on gender in learning PJOK, (3) there is a differnce in the level of honesty character from the treatment of Jigsaw learning models and teams games tournament in PJOK learning, (4) there is no differnce in the level of honesty character based on gender in PJOK learning.
\end{abstract}

Keywords: Jigsaw learning models; teams games tournament; social caring; honesty; PJOK learning

\begin{abstract}
Abstrak
Penelitian ini pada umumnya bertujuan untuk mengungkapkan perbedaan tingkat karakter kepedulian sosial dan kejujuran berdasarkan gender yang dihasilkan dari pembelajaran pendidikan jasmani olahraga kesehatan (PJOK) melalui perlakuan model pembelajaran Jigsaw dan team games tournament. Metode penelitian yang digunakan adalah penelitian eksperimen dengan desain faktorial $2 \mathrm{x} 2$. Instrumen yang digunakan adalah kuisioner angket karakter kepedulian sosial dan kejujuran yang telah divalidasi dan diisi oleh peserta didik yang mengikuti program penelitian. Data penelitian yang dikumpulkan berupa hasil data pretest dan posttest yang diproses melalui program SPSS 20 dengan uji hipotesis analisis two way-anova faktorial. Hasil penelitian ini dapat disimpulkan bahwa (1) tidak terdapat perbedaan tingkat karakter kepedulian sosial dari perlakuan model pembelajaran Jigsaw dan team game toumament dalam pembelajaran PJOK, (2) tidak terdapat perbedaan tingkat karakter kepedulian sosial berdasarkan gender dalam pembelajaran PJOK, (3) terdapat perbedaan tingkat karakter kejujuran dari perlakuan model pembelajaran Jigsaw dan team games tournament dalam pembelajaran PJOK, (4) tidak terdapat perbedaan tingkat karakter kejujuran berdasarkan gender dalam pembelajaran PJOK.
\end{abstract}

Katakunci: model pembelajaran Jigsaw; team game tournamen; kepedulian sosial; kejujuran; pembelajaran PJOK 


\section{Pendahuluan}

Pendidikan merupakan sarana yang dapat digunakan generesi penerus bangsa untuk dapat meningkatkan kemampuan dan potensi yang dimilikinya. Melalui pendidikan juga diyakini mampu memberikan bekal manusia dengan keterampilan dan wawasan (ilmu) yang dapat berguna untuk kehidupan dimasa yang akan datang. Selain sebagai sarana dalam meningkatkan kualitas generasi penerus bangsa, pendidikan juga mampu menciptakan manusia yang unggul dan memiliki karakter. Hal ini sebagaimana (Suyanto, 2010) menjelaskan bahwa, "secara sistematis pendidikan mampu meningkatkan martabat setiap manusia secara holistik yang meliputi aspek kognitif (kecerdasan), afektif (karakter, watak, kepribadian unggul), dan psikomotor". Berdasarkan hal tersebut sudah semestinya arah pendidikan ditujukan untuk menciptakan dan mempersiapkan generasi penerus bangsa yang tidak hanya mempunyai kecerdasan dan keterampilan saja namun juga memiliki kepribadian atau karakter yang baik. Oleh karena itu sudah semestinya pendidikan bukan hanya mampu menciptakan generasi penerus bangsa yang memiliki keterampilan dan kecerdasan namun juga dapat membentuk karakter atau watak yang baik.

Karakter menurut (Rokhman, Hum, Syaifudin, \& Yuliati, 2014) merupakan aspek perilaku, perasaan serta tindakan yang saling terkait. Dalam pembelajaran pendidikan jasmani olahraga dan kesehatan (PJOK) disekolah mampu membentuk karakter anak. Pada dasarnya pendidikan anak secara utuh membahas tentang fisik, pikiran dan jiwa. Sedangkan PJOK membahas dalam aspek pengetahuan (kognitif) dan sosial (afektif) dengan fokus utamanya adalah pengembangan fisik dan keterampilan (psikomotor). (National Association for Sport and Physical Education, 2011). Selain itu (Bailey, 2006) menyatakan bahwa, "hasil dari pembelajaran PJOK memberikan keuntungan dalam perkembangan anak pada lima aspek perkembangan yakni perkembangan fisik, afektif, kognitif, sosial dan gaya hidup. Berdasarkan hal tersebut keunggulan dalam beberapa aspek pada perkembangan anak menjadi ciri khas dalam pembelajaran PJOK yang tidak dimiliki mata pelajaran lainnya.

Dalam merealisasikan tujuan pembelajaran PJOK pada (Kementrian Pendidikan dan Kebudayaan, 2013) terdapat kompetensi inti yakni kompetensi inti sikap spiritual, kompetensi inti sikap sosial, kompetensi inti pengetahuan, dan kompetensi inti keterampilan. Dalam kompetensi inti sikap sosial pada pembelajaran PJOK salah satunya adalah menghendaki dan mengamalkan karakter atau perilaku kepedulian sosial dan kejujuran. Oleh karena itu karakter kepedulian sosial dan kejujuran merupakan kompetensi inti yang perlu direalisasikan pada proses pembelajaran PJOK.

Karakter kepedulian sosial pada umumnya lebih sering dipahami sebagai perilaku baik yang dilakukan setiap individu terhadap individu lain dilingkungan sekitarnya. Menurut (Yaumi, 2014) kepedulian sosial dapat diartikan sebagai sikap saling ketergantungan antar individu dengan individu lainnya sebagai makhluk yang tidak dapat hidup secara mandiri. Selain itu (Soenarko \& Mujiwati, 2015) mendeskripsikan kepedulian sosial sebagai sikap memperhatikan urusan orang lain untuk saling memahami, saling tolong menolong, saling menyayangi dan saling memberi sesuatu kepada seseorang yang membutuhkan.

Dalam memahami kepedulian sosial tak terluput dari kesadaran sosial. Kesadaran sosial menurut (Malik, Taufik, \& Prianti Lestari Puji, 2008) merupakan kemampuan untuk memahami arti dari situasi sosial yang terdapat didalamnya berbagai nilai-nilai sosial. Nilai-nilai sosial tersebut menurut (Zubaedi, 2011) terdiri dari berbagai sub nilai yaitu (1) loves (kasih sayang) yang terdiri dari beberapa indikator nilai seperti nilai tolong menolong terhadap orang yang membutuhkan dan bersimpati terhadap kesulitan orang lain, (2) responsibility (tanggung jawab) yang terdiri dari nilai disiplin (waktu, aturan, serta perilaku), dan empati terhadap keadaan serta perasaan orang lain, (3) life barmony (keserasian hidup) yang terdiri dari nilai kerjasama dan menghormati orang lain. Berdasarkan hal tersebut indikator karakter kepedulian sosial meliputi sikap saling tolong menolong terhadap orang 
yang membutuhkan, sikap simpati atau mampu memahami kesulitan orang lain, sikap disiplin (mengindahkan aturan, waktu dan perilaku), sikap saling bekerjasama, dan sikap saling menghormati satu sama lain.

Sedangkan karakter jujur merupakan karakter atau sikap yang wajib dimiliki setiap orang. Menurut (Ngainun, 2014) karakter jujur merupakan tindakan tidak berbohong, lurus hati dan tindakan tidak curang. Sedangkan (Syarbini, 2016) mengartikan kejujuran sebagai perilaku atau tindakan yang berdasarkan pada usaha seseorang dalam menjadikan dirinya selalu dapat dipercaya dalam perbuatan (tindakan), pekerjaan serta perkataan. Dalam permainan olahraga kejujuran dapat juga dilihat sebagai perbuatan yang tidak melanggar aturan yang berlaku. Hal tersebut sebagaimana (Guenin, 2005) mendefinisikan kejujuran sebagai kecenderungan perilaku atau perbuatan tidak mencuri, tidak menipu atau curang, dan tidak melanggar norma-norma aturan permainan yang adil.

Dalam karakter kejujuran (Mutohir, 2011) mengklarifikasikannya dalam beberapa dimensi indikator yakni truthfullness, candid, sincere, dan forthtight. Dimensi truthfullness merupakan suatu bentuk tindakan jujur dalam artian berbicara dengan tidak berbohong sesuai fakta dan keadaan yang ada seperti halnya menjauhi kebohongan dalam tindakan maupun sikap badan (mengakui kelemahan serta keterbatasan diri). Dimensi sincere merupakan kunci utama dari tindakan kejujuran yaitu perbuatan yang menunjukkan ketulusan hati dan tidak berbohong dalam bertindak seperti patuh dalam aturan yang ada tanpa harus melanggarnya. Dimensi candid merupakan tindakan jujur yang menunjukkan perbuatan yang tidak menyembunyikan kebohongan maupun kecurangan dari sebuah aturan yang berlaku. Dimensi forthright merupakan dimensi tindakan jujur yang dimana langsung berterus terang dengan perkataan untuk dapat menunjukkan tindakan kecurangan atau kesalahan yang dilakukanya maupun yang dilakukan orang lain tanpa harus menutupinya seperti halnya spontan dalam menunjukkan kebenaran ataupun kesalahan (kecurangan) yang ditemuinya.

Dalam proses pembelajaran PJOK guru wajib mengembangkan karakter kepedulian sosial dan kejujuran dalam hal ini pada aspek afektif dan merupakan kompetensi inti dalam pembeljaran PJOK. Oleh karena itu setelah mendapatkan pembelajaran PJOK peserta didik tidak hanya dapat mengembangkan pengetahuan dan menguasai keterampilan saja namun juga karakter kepedulian sosial dan kejujuran dapat meningkat dan berkembang. Secara logika peranan pembelajaran PJOK mampu membentuk atau meningkatkan karakter kepedulian sosial dan kejujuran dapat tercapai ketika peserta didik berpartisipasi aktif dalam berbagai aktifitas pembelajaran PJOK. Dalam bentuk sederhananya tingkat partisipasi peserta didik yang tinggi dalam pembelajaran PJOK akan mempunyai karakter kepedulian sosial dan kejujuran lebih tinggi daripada peserta didik yang tingkat partisipasinya mengikuti pembelajaran PJOK rendah.

Berdasarkan beberapa hasil penelitian terdahulu yang telah dilakukan terdapat inkonsistensi hasil. Pada penelitian yang dilakukan (Bailey, 2006) menjelaskan bahwa, "peserta didik wanita jauh lebih rendah tingkat partisipasi dalam mengikuti aktivitas pembelajaran PJOK daripada laki-laki". Namun pada penelitian (Avşar, Öztürk Kuter, Sözcükler, Beceri, \& Eğitimi ve Spor Bölümü Öğrencisi, 2007) menyebutkan bahwa, "hasil keterampilan sosial dalam PJOK peserta didik wanita mendapatkan skor yang lebih tinggi daripada peserta didik pria". Suatu hal yang menarik adalah bagaimana peserta didik wanita jauh lebih baik daripada peserta didik pria jika partisipasi dalam mengikuti aktifitas pembelajaran PJOK lebih rendah daripada peserta didik pria. Oleh karena itu dalam penelitian ini aktivitas pembelajaran PJOK yang bagaimana yang dapat meningkatkan karakter kepedulian sosial dan kejujuran.

Dalam aktifitas pembelajaran PJOK banyak model pembelajaran yang dapat diterapkan untuk dapat mencapai tujuan pembelajaran PJOK. Salah satunya adalah menerapkan model pembelajaran kooperatif yang dapat mengembangkan karakter kepedulian sosial dan kejujuran. Hal ini 
XI IPA 4 dengan jumlah (pria 21 orang dan wanita 15 orang dalam kelas model pembelajaran teams games tournament).

Instrumen test penelitian ini menggunakan kuisioner karakter kepedulian sosial dan angket karakter kejujuran. Instrumen angket ini menggunakan skala likert dengn pilihan jawaban SL (selalu dilakukan), SR (sering dilakukan), KD (kadang dilakukan,kadang tidak), PD (pernah dilakukan), TPD (tidak pernah dilakukan). Instrumen angket karakter kepedulian sosial sudah divalidasi oleh tiga orang ahli sebagai expert judgement dan memiliki total item 36 pertanyaan dengan nilai reliabilitas cronbach alpha 0,934 atau 93,4\% yang dapat dikategorikan istimewa yang berarti memenuhi syarat. Adapun kisi-kisi pada angket karakter kepedulian sosial penelitian ini sesuai pendapat (Zubaedi, 2011), karakter kepedulian sosial terdiri dari berbagai indikator nilai sosial sebagai berikut:

Tabel 2. Kisi-Kisi Angket Karakter Kepedulian Sosial

\begin{tabular}{|c|c|c|c|}
\hline \multirow[b]{2}{*}{$\begin{array}{l}\quad \text { Variabel } \\
\text { Karakter } \\
\text { kepedulian } \\
\text { sosial } \\
\text { (Zubaedi, } \\
\text { 2011) }\end{array}$} & Sub nilai variabel & Indikator nilai & Keterangan \\
\hline & $\begin{array}{l}\text { Love } \\
\text { (Kasih sayang) }\end{array}$ & $\begin{array}{l}\text { Tolong menolong terhadap orang } \\
\text { yang mebutuhkan saat pembelajaran } \\
\text { PJOK } \\
\text { Bersimpati terhadap orang lain yang } \\
\text { mengalami kesulitan saat } \\
\text { pembelajaran PJOK }\end{array}$ & - $\quad 1,2,3,4,5,6$ \\
\hline & $\begin{array}{l}\text { Responsibility } \\
\text { (Tanggungjawab) }\end{array}$ & $\begin{array}{l}\text { Disiplin dengan aturan yang dibuat } \\
\text { guru PJOK } \\
\text { Berempati terhadap perasaan dan } \\
\text { keadaan orang lain saat pembelajaran } \\
\text { PJOK }\end{array}$ & $\begin{array}{ll}- & 11,12,13,14,15,16, \\
& 17,18 \\
-\quad & 19,20,21,22,23,24\end{array}$ \\
\hline & $\begin{array}{l}\text { Lifer barmony } \\
\text { (Keserasian hidup) }\end{array}$ & $\begin{array}{l}\text { - Saling bekerjasama dalam proses } \\
\text { pembelajaran PJOK } \\
\text { - Saling menghormati dan menghargai } \\
\text { orang lain saat diskusi kelas } \\
\text { pembelajaran PJOK }\end{array}$ & $\begin{array}{ll}- & 25,26,27,28,29,30 \\
- & 31,32,33,34,35,36\end{array}$ \\
\hline
\end{tabular}

Sedangkan angket karakter kejujuran terdiri dari 20 item pertanyaan yang sudah divalidasi oleh tiga orang ahli sebagai expert judmen dan memiliki nilai reliabilitas cronbach alpha 0,890 dengan presentase $89 \%$ memenuhi syarat dengan kategori istimewa. adapun kisi-kisi instrumen angket kejujuran dalam penelitian ini sesuai dengan pendapat (Mutohir, 2011), karakter kejujuran meliputi berbagai dimensi berikut ini:

Tabel 3. Kisi-Kisi Angket Karakter Kejujuran

\begin{tabular}{lllc}
\hline \multicolumn{1}{c}{ Variabel } & Dimensi & Indikator & Keterangan \\
\hline Karakter & Truthfulness & - Mengakui kelemahan dan keterbatasan diri dalam proses & $-1,2,3,4,5$ \\
kejujuran & & pembelajaran PJOK & \\
menurut & Sincere & - Mematuhi aturan yang ada pada pembelajaran PJOK & $-6,7,8,9,10$ \\
(Mutohir, & Candid & - Tidak menyembunyikan kebohongan/kecurangan dari & $-11,12,13,14$, \\
2011) & sebuah aturan permainan dalam pembelajaran PJOK & 15 \\
& Forthright & - Berterus terang dengan menunjukkan kebenaran ataupun & $-16,17,18,19$, \\
& & kesalahan (kecurangan) yang ditemuinya saat pembelajaran & 20 \\
& & & \\
& & & \\
\end{tabular}

Prosedur penelitian ini dimulai dengan melakukan pretest angket karakter kepedulian sosial dan kejujuran terhadap kedua kelompok kelas model pembelajaran. Setelah memberikan pretest lalu memberikan perlakuan sesuai dalam kelas pada masing-masing kelompok model pembelajaran saat pembelajaran PJOK dengan kompetensi dasar permainan bola besar. Jumlah pertemuan perlakuan 
dilakukan sebanyak 6 kali pertemuan pada setiap kelas kelompok model pembelajaran yang disesuaikan dengan silabus SMA Trimurti Surabaya dengan durasi 2x45 menit.

Dalam kelas model pembelajaran Jigsaw perlakuan diberikan dengan langkah-langkah sebagai berikut: (1) peserta didik dibagi dalam kelompok menjadi 5-6 orang berdasarkan kemampuan dan gender (jenis kelamin), (2) tunjuk saru siswa dalam setiap kelompok sebagai ketua, (3) bagilah pelajaran hari itu menjadi 5-6 segmen yang disesuaikan dengan jumlah kelompok, (4) tugasi peserta didik untuk belajar satu segmen/materi mereka sendiri, (5)beri peserta didik beberapa waktu agar membaca materi mereka agar terbiasa dan tidak perlu menghafal, (6)bentuk kelompok/tim ahli sementara dari satu siswa pada setiap kelompok asal dan bergabung dengan peserta didik yang lain yang ditugaskan kesegmen yang sama dan beri waktu peserta didik untuk membahas poin materinya untuk latihan presentasi yang akan mereka buat didalam kelompok asal, (7) intruksikan peserta didik kembali ke dalam kelompok asal, (8) intruksikan peserta didik dari kelompok ahli untuk mempresentasikan materi yang didapatnya ke dalam kelompok asal, (9) keliling dan amati dari kelompok ke kelompok lainnya untuk memastikan siswa dari kelompok ahli membuat intervensi ke siswa kelompok asal agar menguasai materi, (10) berikan kuis di akhir sesi tentang materi yang dipelajari. (Mari \& Gumel, 2015).

Sedangkan model pembelajaran teams games tournamen (Sofya, 2018) menjelaskan bahwa, "salah satu model pembelajaran kooperatif yang menempatkan peserta didik dalam 5 hingga 6 kelompok belajar yang berbeda kemampuan, jenis kelamin, dan etnis. Dalam kelas model pembelajaran teams games tournament perlakuan dilakukan sesuai dengan rekomendasi (Slavin, 2008) dengan langkahlangkah berikut ini: (1) presentasi kelas dalam pembelajaran ini seperti pelajaran biasa pada umumnya dilakukan guru namun pelajaran lebih terfokus pada materi yang dibahas, (2) bentuklah tim atau kelompok dengan beranggotakan 4-5 orang setiap tim berdasarkan gender dan kemampuan akademik yang dimiliki peserta didik, (3) siswa saling berdiskusi tentang materi pembelajaran dalam masing-masing kelompok, (4) merancang dan melakukan kegiatan permainan (games) akademik yang disusun dari materi pembelajaran yang relevan untuk menguji masing-masing anggota kelompok. (5) melakukan kegiatan turnamen/kompetisi yang terdiri dari beberapa pertandingan dalam meja tournamen yang terdiri dari 3-5 orang dari setiap anggota kelompok/tim yang berbeda dengan skill (kemampuan) yang sama dan pada pertemuan awal pengaturan meja tournamen diumumkan kepada siswa, (6) lakukan rekognisi dengan memberikan penghargaan dan masukan terhadap pemahaman materi setiap anggota kelompok.

Dalam setiap pertemuan kelas model pembelajaran Jigsaw dan team games tournament tercantum dalam RPP yang tertuliskan dalam sketsa pembelajaran. Sketsa pembelajaran tersebut terdiri dalam tiga kegiatan pembelajaran yakni pendahuluan, inti, dan penutupan. Pada kegiatan pendahuluan dan penutup berisi dengan kegiatan yang sama namun perbedaanya terdapat pada kegiatan inti pembelajaran yang disesuaikan dengan langkah-langkah model pembelajaran Jigsaw dan team games toumament. Setelah kegiatan perlakuan selesai di akhir pertemuan langkah selanjutnya adalah melaksanakan kegiatan posttest dengan instrumen angket kepedulian sosial dan kejujuran yang sama seperti kegiatan pretest.

Dalam penelitian ini pengujian hipotesis dilakukan menggunakan program SPSS versi 20 dengan uji hipotesis two-way anova faktorial. Pengujian ini dilakukan untuk menguji perbedaan diantara kelompok data yang berasal dari dua variabel bebas atau lebih. (Maksum, 2012). Dalam penelitian ini data pretest dapat dijadikan covariat karena berskala kuantitatif sedangkan data posttest dapat dijadikan variabel terikat (dependent variable). Hal tersebut menunjukkan seberapa besar pengaruh covariat terhadap variabel terikat dengan signifikansi $<0,05$ yang memiliki arti terdapat pengaruh perbedaan. Sedangkan model pembelajaran Jigsaw maupun teams games tournament dan gender merupakan variabel dengan skala kualitatif sehingga menjadi peubah bebas atau fixed factor. 
Pengaruh Model Pembelajaran Jigsaw dan Teams Games Tournament Terhadap Karakter Kepedulian Sosial dan Kejujuran dalam

Pendidikan Jasmani Olahraga Kesehatan

\section{Hasil}

Hasil penelitian ini dapat dijabarkan sebagai berikut:

Tabel 4. Hasil Nilai Rata-Rata Posttest Angket Karakter Kepedulian Sosial

\begin{tabular}{ccccc}
\hline $\begin{array}{c}\text { Model } \\
\text { Pembelajaran }\end{array}$ & $\begin{array}{c}\text { Gender/ } \\
\text { Jenis Kelamin }\end{array}$ & Mean & $\begin{array}{c}\text { Standart } \\
\text { Deviation }\end{array}$ & N \\
\hline Kelas & Pria & 142,60 & 9,949 & 20 \\
Jigsaw & Wanita & 136,86 & 11,759 & 14 \\
& Jumlah & 140,24 & 10,941 & 34 \\
Kelas Teams Game & Pria & 139,76 & 6,332 & 21 \\
Tournament & Wanita & 138,93 & 10,647 & 15 \\
& Jumlah & 139,42 & 8,272 & 36 \\
Jumlah & Pria & 141,15 & 8,314 & 41 \\
& Wanita & 137,93 & 11,045 & 29 \\
& Jumlah & 139,81 & 9,598 & 70 \\
\hline
\end{tabular}

Berdasarkan tabel 4 tersebut diperoleh nila rata-rata (mean) posttest angket karakter kepedulian sosial dalam model pembelajaran Jigsaw peserta didik bergender pria sebesar 142,60 lebih besar daripada kelas model pembelajaran team games toumament peserta didik bergender pria sebesar 139,76. Sedangkan nilai rata-rata (mean) karakter kepedulian sosial dalam model pembelajaran Jigsaw peserta didik bergender wanita sebesar 136,86 lebih kecil daripada model pembelajaran team games tournament peserta didik bergender wanita sebesar 138,96. Sedangkan nilai rata-rata (mean) jumlah keseluruhan pada model pembelajaran Jigsaw sebesar 140,24 lebih besar daripada model pembelajaran team games tournament 139,42. Namun jika dilihat nilai selisih rata-rata (mean) tersebut tidak terlampau jauh oleh karena itu perlu dianalisis statistik dengan two-way anova faktorial.

Tabel 5. Hasil Nilai Rata-Rata Posttest Angket Karakter Kejujuran

\begin{tabular}{ccccc}
\hline $\begin{array}{c}\text { Model } \\
\text { Pembelajaran }\end{array}$ & $\begin{array}{c}\text { Gender/ } \\
\text { Jenis Kelamin }\end{array}$ & Mean & $\begin{array}{c}\text { Standart } \\
\text { Deviation }\end{array}$ & N \\
\hline Kelas & Pria & 74,10 & 2,770 & 20 \\
Jigsaw & Wanita & 72,07 & 3,912 & 14 \\
& Jumlah & 73,26 & 3,387 & 34 \\
Kelas Teams Game & Pria & 77,29 & 2,493 & 21 \\
Tournament & Wanita & 77,60 & 4,485 & 15 \\
& Jumlah & 77,42 & 3,409 & 36 \\
Jumlah & Pria & 75,73 & 3,058 & 41 \\
& Wanita & 74,93 & 5,007 & 29 \\
& Jumlah & 75,40 & 3,969 & 70 \\
\hline
\end{tabular}

Berdasarkan tabel 5 tersebut diperoleh nila rata-rata (mean) posttest angket karakter kejujuran dalam model pembelajaran Jigsaw peserta didik bergender pria sebesar 74,10 lebih kecil daripada kelas model pembelajaran team games tournament peserta didik bergender pria sebesar 77,29 . Sedangkan nilai rata-rata (mean) angket kejujuran dalam model Jigsaw peserta didik bergender wanita sebesar 72,07 lebih kecil daripada model pembelajaran team games tournament peserta didik bergender wanita sebesar 77,60. Sedangkan nilai rata-rata (mean) jumlah keseluruhan pada model Jigsaw sebesar 73,26 lebih kecil daripada model pembelajaran team games tournament sebesar 77,42. Namun jika dilihat nilai selisih rata-rata (mean) tersebut tidak terlampau jauh oleh karena itu perlu dianalisis statistik dengan two-way anova faktorial. 
Pengaruh Model Pembelajaran Jigsaw dan Teams Games Tournament Terhadap Karakter Kepedulian Sosial dan Kejujuran dalam

Pendidikan Jasmani Olahraga Kesehatan

Tabel 6. Hasil Uji Homogenitas Pretest dan Posttest Karakter Kepedulian Sosial

\begin{tabular}{lcccc}
\hline & $\begin{array}{c}\text { Levene } \\
\text { Statistic }\end{array}$ & df1 & df2 & Sig. \\
\hline Pretest Kepedulian Sosial & 1.026 & 1 & 68 & .315 \\
Posttest Kepedulian Sosial & 2.337 & 1 & 68 & .131 \\
\hline
\end{tabular}

Sebelum melakukan uji hipotesis maka untuk memenuhi syarat wajib di uji homegenitas. Berdasarkan tabel 6 di atas pretest kepedulian sosial nilai sig. 0.315 lebih besar dari 0.05 maka data dinyatakan homogen.(Maksum, 2012). Sedangkan posttest kepedulian sosial nilai sig. 0.131 lebih besar dari 0.05 maka data juga dinyatakan homogen. Dengan demikian data hasil pretest dan posttest karakter kepedulian sosial dapat dilanjutkan ke uji hipotesis two-way anova faktorial.

Tabel 7. Hasil Uji Two-Way Anova Faktorial Karakter Kepedulian Sosial

\begin{tabular}{lcccrc}
\hline \multicolumn{1}{c}{ Source } & $\begin{array}{c}\text { Type III Sum } \\
\text { of Squares }\end{array}$ & df & $\begin{array}{c}\text { Mean } \\
\text { Square }\end{array}$ & F & sig. \\
\hline Corrected Model & $4568,919^{\mathrm{a}}$ & 4 & 1142,230 & 41,532 & 0,000 \\
Intercept & 9311,671 & 1 & 9311,671 & 338,575 & 0,000 \\
Pretest Kepedulian & 4279,590 & 1 & 4279,590 & 155,607 & 0,000 \\
Kelas Model Pembelajaran & 4,400 & 1 & 4,400 &, 160 & 0,690 \\
Gender & 75,179 & 1 & 75,179 & 2,734 & 0,103 \\
Kelas model & 88,802 & 1 & 88,802 & 3,229 & 0,77 \\
pembelajaran*Gender & 1787,667 & 65 & 27,503 & & \\
Eror & 1374719,000 & 70 & & & \\
Total & 6356,586 & 69 & & & \\
Corrected Total & & & & & \\
\hline
\end{tabular}

Berdasarkan perolehan hasil uji analisis two-way anova faktorial yang dilakukan dapat diketahui pada tabel 7 nilai signifikan kelas model pembelajaran sebesar $0,690>$ sig. 0,05, maka hipotesis awal diterima yang berarti tidak ada perbedaan peningkatan karakter kepedulian sosial dari perlakuan model pembelajaran Jigsaw dengan team games tournament. Sedangkan nilai signifikan gender sebesar 0,103 > sig. 0,05, maka hipotesis awal diterima yang berarti tidak ada perbedaan tingkat karakter kepedulian sosial berdasarkan gender dalam pembelajaran PJOK.

Tabel 8. Hasil Uji Homogenitas Pretest dan Posttest Karakter Kejujuran

\begin{tabular}{llllll}
\hline & $\begin{array}{c}\text { Levene } \\
\text { Statistic }\end{array}$ & df1 & df2 & Sig. \\
\hline Pretest karakter jujur &, 767 & 1 & 68 & .384 \\
Posttest karakter jujur & 1,972 & 1 & 68 & .165 \\
\hline
\end{tabular}

Berdasarkan tabel 8 diatas pretest karakter kejujuran nilai sig. 0.384 lebih besar dari 0.05 maka data dinyatakan homogen (Maksum, 2012). Sedangkan posttest karakter kejujuran nilai sig. 0.165 lebih besar dari 0.05 maka data juga dinyatakan homogen. Dengan demikian data pretest dan posttest karakter kejujuran dapat dilanjutkan ke uji hipotesis two-way anova faktorial. 
Pengaruh Model Pembelajaran Jigsaw dan Teams Games Tournament Terhadap Karakter Kepedulian Sosial dan Kejujuran dalam

Pendidikan Jasmani Olahraga Kesehatan

Tabel 9. Hasil Uji Two-Way Anova Faktorial Karakter Kejujuran

\begin{tabular}{lrrrrr}
\hline \multicolumn{1}{c}{ Source } & $\begin{array}{c}\text { Type III Sum } \\
\text { of Squares }\end{array}$ & df & $\begin{array}{c}\text { Mean } \\
\text { Square }\end{array}$ & F & sig. \\
\hline Corrected Model & $454,291^{a}$ & 4 & 113,573 & 11,671 & 0,000 \\
$\begin{array}{l}\text { Intercept } \\
\text { Pretest karakter } \\
\text { kejujuran }\end{array}$ & 240,372 & 1 & 240,372 & 24,702 & 0,000 \\
$\begin{array}{l}\text { Kelas Model } \\
\text { Pembelajaran }\end{array}$ & 118,105 & 1 & 118,105 & 12,137 & 0,001 \\
$\begin{array}{l}\text { Gender } \\
\text { Kelas model } \\
\text { pembelajaran*Gender }\end{array}$ & 363,441 & 1 & 363,441 & 37,349 & 0,000 \\
$\begin{array}{l}\text { Eror } \\
\text { Total }\end{array}$ & 26,280 & 1 & & & \\
Corrected Total & & & 26,280 & 2,701 & 0,776 \\
\hline
\end{tabular}

Berdasarkan tabel 9 perolehan hasil uji analisis yang dilakukan pada kelas model pembelajaran sebesar nilai sig. $0,000<$ sig. 0,05, maka hipotesis awal ditolak yang berarti terdapat perbedaan peningkatan karakter kejujuran dari perlakuan model pembelajaran Jigsaw dengan team games tournament. Sedangkan nilai sig. gender sebesar $0,776>$ sig. 0,05 , maka hipotesis awal diterima yang dapat disimpulan tidak ada perbedaan yang signifikan tingkat kejujuran berdasarkan gender dalam pembelajaran PJOK.

\section{Pembahasan}

Berdasarkan hasil penelitian yang diinterpretasikan dalam pertanyaan rumusan masalah penelitian dapat dijabarkan dalam pembahasan berikut ini:

a) Adakah terdapat perbedaan tingkat karakter kepedulian sosial dari perlakuan model pembelajaran Jigsaw dan team games tournament dalam pembelajaran PJOK?

Berdasarkan perolehan hasil uji analisis two-way anova faktorial yang dilakukan dapat diketahui pada tabel 7 nilai signifikan kelas model pembelajaran sebesar $0,690>$ sig. 0,05 , maka hipotesis awal diterima yang berarti tidak terdapat perbedaan tingkat karakter kepedulian sosial dari perlakuan model pembelajaran Jigsaw dengan teams games tournament dalam pembelajaran PJOK. Tidak ada perbedaan karakter kepedulian sosial ini sesuai dengan penelitian (Suherman, 2016) yang menyatakan bahwa secara perhitungan statistik terdapat perbedaan keterampilan sosial dan skill bermain bola voli kelompok pembelajaran Jigsaw dan team games tournament tidak ada perbedaan yang signifikan. Dalam penelitian ini tingkat kepedulian sosial juga tidak ada perbedaan karena model pembelajaran Jigsaw maupun team games tournament merupakan model pembelajaran kooperatif yang memiliki beberapa karakteristik seperti halnya interaksi tatap muka, saling ketergantungan positif, pertanggung jawaban indivdu (individual accountability), keterampilan sosial dan terdapat pengolahan kelompok (group processing). (A. R. Adams, 2013).

Dengan adanya interaksi tatap muka harapannya adalah peserta didik mampu saling menyelesaikan masalah dalam menguasai sebuah materi dengan saling menjelaskan satu sama lain dengan yang membutuhkan. Saling ketergantungan yang positif menjadikan keyakinan peserta didik saling terkait dengan peserta didik lainnya sedemikian rupa sehingga seseorang peserta didik tidak dapat berhasil kecuali semua anggota kelompok juga ikut berhasil. Pertanggungjawaban individu juga merupakan prasyarat peserta didik untuk dapat menyelesaikan bagian dari pekerjaannya (pemahaman materinya) jika ikut berpartisipasi aktif dalam menguasai materi selama proses pembelajaran. Keterampilan 
sosial juga diperlukan dalam mencapai tujuan bersama sehingga peserta didik saling berkomunikasi efektif dan saling mendorong serta mendukung satu sama lain hal ini juga dapat meningkatkan karakter kepedulian sosial.

Selama intervensi pembelajaran kooperatif menurut (F. H. Adams, 2013) peserta didik memainkan peran dan memiliki tugas masing-masing seperti halnya bekerja sama, mendengarkan satu sama lain, mempertanyakan satu sama lain, menyimpan catatan pekerjaan dan kemajuan mereka, dan menghasilkan tugas penilaian dengan asumsi tanggungjawab pribadi terlibat dalam kelompok. Dalam penelitian ini model pembelajaran Jigsaw pada proses pembelajaran PJOK juga memiliki tugas saling bekerja sama untuk menguasai materi pembelajaran baik di dalam kelompok asal maupun kelompok ahli, mendengarkan atau bersimpati terhadap keluhan atau saran satu sama lain antar siswa mengenai materi pembelajaran, dan bertanggung jawab atas keberhasilan dalam menguasai materi sendiri maupun keberhasilan teman dalam kelompoknya.

Sedangkan dalam model pembelajaran team games toumament menurut (Risma, 2014) menjelesakan bahwa, "model pembelajaran teams games tournamen merupakan pembelajarannya yang menekankan pada pembelajaran pada kelompok-kelompok, Oleh karena itu dalam kemajuan kelompok untuk dapat menguasai materi pembelajaran peserta didik menyadari peranannya dan berkontribusi dengan cara saling bekerjasama, saling menghormati dan menghargai peranan dan keberadaan peserta didik lainnya". Dengan situasi pembelajaran Jigsaw maupun teams games toumament yang dijelaskan tersebut kedua model pembelajaran tidak memiliki perbedaan tingkat karakter kepedulian sosial. Sehingga keduanya dapat direkomendasikan dalam meningkatkan kepedulian sosial peserta didik pada pembelajaran PJOK.

b) Adakah terdapat perbedaan tingkat kepedulian sosial berdasarkan gender dalam pembelajaran PJOK?

Berdasarkan tabel 7 nilai signifikan gender sebesar 0,103 > sig. 0,05, maka hipotesis awal diterima yang berarti tidak ada perbedaan tingkat karakter kepedulian sosial berdasarkan gender/jenis kelamin dalam pembelajaran PJOK. Tidak ada perbedaan tingkat kepedulian sosial antara peserta didik gender pria dan wanita dikarenakan semua peserta didik pria maupun wanita ikut berpartisipasi aktif dalam proses pembelajaran PJOK tanpa membedakan gender sehingga memberikan pengalaman yang sama dalam peningkatan kepedulian sosial sebagai hasil pembelajaran PJOK. Hal ini sebagaimana (Tirtarahardja, U \& Sulo, 2005) menyatakan bahwa, "pendidikan merupakan transformasi budaya yang mewariskan suatu budaya dari satu generasi kegenerasi lainnya, sehingga pendidikan sangat penting bagi setiap manusia karena proses pendidikan tidak membedakan gender dalam tindakan dan cara memperolehnya".

c) Adakah terdapat perbedaan tingkat karakter kejujuran dari perlakuan model pembelajaran Jigsaw dan team games tournamen dalam pembelajran PJOK?

Berdasarkan tabel 8 perolehan hasil uji analisis yang dilakukan pada kelas model pembelajaran sebesar nilai sig. $0,000<$ sig. 0,05 , maka hipotesis awal ditolak yang berarti terdapat perbedaan peningkatan karakter kejujuran dari perlakuan model pembelajaran Jigsaw dengan team games tournament. Terdapat perbedaan tingkat karakter jujur tersebut terlihat dalam tabel 5 yang menjelaskan jumlah keseluruhan kelas model pembelajaran Jigsaw sebesar 73,26 <77,42 pada kelas team games tournament. Ini berarti kelas teams games tournamen lebih baik daripada kelas model pembelajaran Jigsaw.

Berdasarkan hal tersebut nilai karakter jujur pada kelas teams games tournamen pada saat pembelajaran PJOK lebih baik karena dalam langka-langkah model pembelajaran teams games 
tournamen terdapat persaingan permainan (games) akademik antar anggota tim dengan yang anggota tim lainnya sehingga dituntut untuk jujur dalam permainan. Hal ini sesuai dengan pernyataan (A. R. Adams, 2013) yang menjelaskan bahwa, "model pembelajaran teams games tournament dalam pembelajarannya siswa ditempatkan dalam kelompok dan bersaing dalam bidang akademik dengan anggota tim lainnya dan berkontribusi poin untuk skor tim mereka”.

Dengan situasi belajar dalam model teams games tournamen diharapkan seluruh peserta didik dapat jujur dalam melakukan setiap tindakan dalam proses pembelajaran. Oleh karena itu memungkinkan peserta didik dapat memupuk karakter kejujuran pada proses pembelajaran teams games tournament yang lebih baik. Hal tersebut sebagaimana (Kamaruddin \& Yusoff, 2019) menjelaskan bahwa dalam pembelajaran menggunakan model teams games tournamen kegiatan pembelajarannya melibatkan fungsi peserta didik sebagai pengajar atau teman sebaya sebagai tutor dan didalamnya mengandung kegiatan permainan dan reinforcement yang memungkinkan peserta didik dapat memupuk tanggungjawab, kejujuran, kerjasama, kompetisi sehat dan keterlibatan belajar aktif.

Sedangkan model pembelajaran Jigsaw tidak terdapat persaingan permainan (games) akademik sebagaimana (Miaz, 2015) merekomendasikan model pembelajaran Jigsaw kegiatan pembelajarannya dapat diatur dalam lima instruksional kegiatan yaitu; peserta didik membaca materi untuk mendapatkan sebuah informasi, diskusi dalam kelompok ahli dengan cara peserta didik dengan topik team ahli yang sama bertemu dalam kelompok ahli untuk membahas materi topik ahli tersebut, diskusi kelompok yang dilakukan kelompok ahli kembali kedalam kelompok asalnya untuk menjelaskan materi topik ahli, memberikan kuis kepada setiap peserta didik mencakup keseluruhan materi topik, memberikan penghargaan kelompok yang terbaik dalam mencapai keberhasilan memahami materi topik.

\section{d) Adakah terdapat perbedaan tingkat kejujuran berdasarkan gender dalam pembelajran PJOK?}

Berdasarkan tabel 8 nilai sig. gender sebesar $0,776>$ sig. 0,05 , maka hipotesis awal diterima yang dapat disimpulkan bahwa tidak ada perbedaan tingkat kejujuran berdasarkan gender/jenis kelamin dalam pembelajaran PJOK. Dalam meningkatkan karakter kejujuran saat proses pembelajaran PJOK berlangsung (Jones, 2005) merekomendasikan bahwa, "aktivitas olahraga pada saat pembelajaran dapat mengajari dan membiasakan peserta didik bermain dalam sebuah permainan secara adil, menjadikan pemenang yang sederhana untuk menghormati lawan mereka dan membuat peserta didik memiliki karakter yang kuat untuk membuat suatu pilihan yang tepat ketika ujian atau pencobaan yang menghalangi mereka seperti tindakan jujur seperti halnya jangan menipu, berbohong, dan curang". Dengan aktivitas olahraga pada saat pembelajaran PJOK tersebut semua peserta didik pria maupun wanita ikut berpartisipasi aktif dalam proses pembelajaran sehingga tidak membedakan pengalaman yang diberikan kepada semua peserta didik pria maupun wanita agar menampilkan karakter atau tindakan jujur seperti jangan menipu, berbohong maupun curang sebagai hasil pembelajaran.

Hal tersebut sebagaimana (Tirtarahardja, U \& Sulo, 2005) menyatakan bahwa, "pendidikan merupakan transformasi budaya yang mewariskan suatu budaya dari satu generasi kegenerasi lainnya, sehingga pendidikan sangat penting bagi setiap manusia karena proses pendidikan tidak membedakan gender dalam tindakan dan cara memperolehnya”. Sehingga diperoleh dalam penelitian tidak ada perbedaan tingkat karakter kejujuran antara peserta didik gender pria dan wanita tersebut dikarenakan semua peserta didik pria maupun wanita ikut aktif dalam kegiatan proses pembelajaran PJOK tanpa membedakan gender sehingga memberikan pengalaman yang sama dalam peningkatan karakter kejujuran sebagai hasil pembelajaran PJOK. 


\section{Kesimpulan dan Rekomendasi}

Berdasarkan temuan hasil dalam penelitian ini dapat disimpulkan bahwa model pembelajaran Jigsaw dan teams games tournament dalam proses pembelajaran PJOK tidak terdapat perbedaan tingkat karakter kepedulian sosial berdasarkan gender, oleh karena itu model Jigsaw maupun team games tournament dapat direkomendasikan sebagai model pembelajaran yang dapat digunakan dalam pembelajaran PJOK. Namun model pembelajaran teams games tournament memberikan hasil yang lebih baik dalam meningkatkan karakter kejujuran dalam pembelajaran PJOK.

\section{Daftar Pustaka:}

Adams, A. R. (2013). Cooperative Learning Effects on the Classroom. In Journal of Chemical Information and Modeling. https://doi.org/10.1017/CBO9781107415324.004

Adams, F. H. (2013). Using Jigsaw Technique as an Effective Way of Promoting Co-Operative Learning Among Primary Six Pupils in Fijai. International Journal of Education and Practice, 1(6), 64-74. https://doi.org/10.18488/journal.61/2013.1.6/61.6.64.74

Avşar, Z., Öztürk Kuter, F., Sözcükler, A., Beceri, S., \& Eğitimi ve Spor Bölümü Öğrencisi, B. (2007). Determination of Social Skills Level in Students of Uludag University Physical Education and Sports Department. Journal of Theory and Practice in Education Makaleler/Articles ISSN, 3(2), 197-206.

Bailey, R. (2006). Physical education and sport in schools: A review of benefits and outcomes. Journal of School Health, 76(8), 397-401. https://doi.org/10.1111/j.1746-1561.2006.00132.x

Goudas, M., \& Magotsiou, E. (2009). The effects of a cooperative physical education program on students' social skills. Journal of Applied Sport Psychology, 21(3), 356-364. https://doi.org/10.1080/10413200903026058

Guenin, L. M. (2005). Intellectual honesty. Synthese, 145(2), 177-232. https://doi.org/10.1007/s11229-005-3746-3

Jones, C. (2005). Character, virtue and physical education. European Physical Education Review, 11(2), 139-151. https://doi.org/10.1177/1356336X05052893

Kamaruddin, S., \& Yusoff, N. M. R. N. (2019). The Effectiveness of Cooperative Learning Model Jigsaw and Team Games Tournament (TGT) towards Social Skills. Creative Education, 10(12), 2529-2539. https://doi.org/10.4236/ce.2019.1012180

Kementrian Pendidikan Dan Kebudayaan. Peraturan Menteri Pendidikan Dan Kebudayaan Nomor 69 Negara Kesatuan Republik Indonesia. , (2013).

Maksum, A. (2012). Metodologi Penelitian dalam olahraga. Surabaya: Unesa University Press.

Malik, L. H., Taufik, A., \& Prianti Lestari Puji. (2008). Pendidikan anak SD. Jakarta: Universitas Terbuka.

Mari, J. S., \& Gumel, S. A. (2015). Effects of Jigsaw Model of Cooperative Learning on Self-Efficacy and Achievement in Chemistry among Concrete and Formal Reasoners in Colleges of Education in Nigeria. International Journal of Information and Education Technology, 5(3), 196-199. https://doi.org/10.7763/ijiet.2015.v5.501

Miaz, Y. (2015). Improving Students' Achievement of Social Science By Using Jigsaw Cooperative Learning Model at Primary School. IOSR Journal of Research \& Method in Education Ver. II, 5(4), 2320-7388. https://doi.org/10.9790/7388-05420107

Mutohir, T. C. (2011). Berkarakter Dengan Berolahraga, Berolahraga Dengan Berkarakter (A. Muhyi, M. F., 
\& Fenanlampir, Ed.). Surabaya: Sport Media.

National Association for Sport and Physical Education. (2011). Physical Education Is Critical to Educating the Whole Child It. National Association for Sport and Physical Education, (703), 1-9.

Ngainun, N. (2014). Character Building. Optimalisasi Peran Pendidikan dalam Pengembangan Ilmu dan Pengenbangan Karakter Bangsa (1st ed.). Jakarta.

Risma. (2014). Pengaruh Model Pembelajaran Dan Jenis Kelamin Terhadap Keterampilan Sosial Siswa Dalam Pendidikan Jasmani Universitas Pendidikan Indonesia | repository.upi.edu | perpustakaan.upi.edu.

Rokhman, F., Hum, M., Syaifudin, A., \& Yuliati. (2014). Character Education for Golden Generation 2045 (National Character Building for Indonesian Golden Years). Procedia - Social and Behavioral Sciences, 141, 1161-1165. https://doi.org/10.1016/j.sbspro.2014.05.197

Slavin, R. E. 2008. (2008). Cooperative Learning Teori Riset dan Praktik. Bandung: Nusa Media.

Soenarko, B., \& Mujiwati, E. S. (2015). Peningkatan Nilai Kepedulian Sosial Melalui Modifikasi Model Pembelajaran Konsiderasi Pada Mahasiswa Tingkat I Program Studi Pgsd Fkip Universitas Nusantara Pgri Kediri Bambang Soenarko, Endang Sri Mujiwati. 26, 33-47.

Sofya, R. (2018). The Implementation of Team Games Tournament to Improve Students' Problem-Solving Skill (Quasi Experiment With Blended Learning Strategy). 57(Piceeba), 624-630. https://doi.org/10.2991/piceeba-18.2018.14

Suherman, A. (2016). Pengaruh Penerapan Model Kooperatif Tipe Jigsaw Dan TGT (Teams Game Tournament) Terhadap Keterampilan Sosial dan Keterampilan Bermain Bolavoli. Jurnal Pendidikan Jasmani Dan Olabraga, 1(2), 8. https://doi.org/10.17509/jpjo.v1i2.5659

Suyanto. (2010). Urgensi Pendidikan Karakter. Jakarta: Kementrian Pendidikan Nasional.

Syarbini, A. (2016). Pendidikan Karakter Berbasis Keluarga. Yogyakarta: Ar-Ruzz Media.

Tirtarahardja, U \& Sulo, L. (2005). Pengantar Pendidikan. Jakarta: PT. Rineka Cipta.

Yaumi, M. (2014). Pendidikan karakter: Landasan, Pilar dan Implementasi. Jakarta: Kencana.

Zubaedi. (2011). Desain Pendidikan Karakter Konsepsi dan Aplikasinya dalam Lembaga Pendidikan (Pertama). Jakarta: Kencana Prenada Media Group. 